\title{
Microplastics abundance in gills and gastrointestinal tract of Epinephelus fuscoguttatus-lanceolatus at the Coastal of Pulau Panjang, Serang, Banten
}

\author{
Afra Nabila $^{1 *}$ and Mufti Petala Patria ${ }^{1}$ \\ ${ }^{1}$ Department of Biology, Faculty of Mathematics and Natural Sciences, Universitas Indonesia, Kampus UI, 16424, Depok, Indonesia
}

\begin{abstract}
Microplastics are plastic particles in the size of $<5 \mathrm{~mm}$. Bioaccumulation of microplastics in the marine biotas, including fishes, occurs through the food chain. Microplastics enter the fish body through their gills and mouth. Contamination of microplastics inside the fish body can cause several effects, such as increasing toxicity effect, and growth inhibition. This research analyzed the form and amount of the microplastics found in each gill and gastrointestinal tract of the fish samples. A total of 15 samples of cantang grouper were taken from the floating net cage near Kampung Peres, Pulau Panjang. Samples were transported to the laboratory using an icebox. The gill and gastrointestinal tract of samples are isolated from their body, then destructed with $\mathrm{HNO}_{3} 65 \%$ for 24 hours. After 24 hours, the samples were mixed with the concentrated $\mathrm{NaCl}$ solution with a ratio of 1:4. Microplastics form and amount are observed under the light microscope with three times repetition. The results show that the microplastics found in the gill and gastrointestinal tract of cantang groupers are mostly found in the form of fragments. The microplastics abundance in gills was 51893,33 $\pm 2594,67$ particles/individual, and in the gastrointestinal tracts was $83926,67 \pm 4196,33$ particles/individual.
\end{abstract}

Keywords: Microplastic, Gastrointestinal tract, Gills, Epinephelus fuscoguttatus-lanceolatus

\section{Introduction}

Marine plastic debris came from the land entering the ocean by any deliberate or accidental actions [1]. East Asia is suspected to be the region with the fastest growing waste production in the world. Based on Geyer et al. [23], out of 192 reviewed countries, five states from the East Asia Region are responsible for more than half of plastic waste in the ocean. Indonesia ranks the second country after China, out of five countries from East Asia. There are 187.2 million tons of plastic waste that came from Indonesia that ends up in the ocean [24]. Microplastics are fragmented plastic that is smaller than $5 \mathrm{~mm}$ in size [2,3]. Microplastics can be divided into four categories based on their shape. There are fragments, fiber, film, and granules [4]. Microplastics that came from the degradation of plastic waste can contribute to a wide range of impacts to many marine biotas, such as feeding disruption, reproductive impairment, metabolism change, and also interaction with the other contaminants [33].

Pulau Panjang, is one of the largest islands in Teluk Banten [7]. Pulau Panjang is one of the islands in Teluk Banten where are many fishing activities done by local fishermen [8]. The fishing area around Pulau Panjang is dominated by various fishing gears such as bottom set gillnet, dogol cantrang, bagan tancap, payang, hand line, and rampus [8]. Not only does plastic waste come from the plastic products, such as plastic bags or plastic bottles, but also various synthetic components from the fishing nets that are used for catching fish are also the other sources of microplastics found in the marine environment [32]. Research by Yudhantari et al. (2019) [9] in Sardinella lemuru digestive tracts shows that fiber type of microplastic is the dominant type found. Based on United Nations Environment Program (2016) [17] the fiber type of microplastic can be dangerous because it can block the digestive tract of the fish.

Epinephelus fuscoguttatus-lanceolatus is one of the fish cultivated in the floating net cage near Kampung Peres, Pulau Panjang, Serang, Banten by local fishermen. E. fuscoguttatus lanceolatus is one of the fishery commodities that have opportunities in domestic and foreign markets [10].

E. fuscoguttatus-lanceolatus or cantang grouper is one of a species from the grouper family, Serranidae, developed in Indonesia because it has a high price in the market. Cantang grouper is a hybrid between female tiger grouper (E. fuscoguttatus) and male giant grouper (E. lanceolatus). It has a similar morphology to tiger grouper [25], fast growth rate such as kertang grouper, easy to breed such as tiger grouper, and low cannibalism compared to tiger grouper [26]. The hybridization technique is a technique that can increase species diversification, also, it has cultivation prospects that

* Corresponding author: afranabilaa@ gmail.com 
have the opportunity to increase fisheries production in the future.

Microplastic ingestion by fish was first explained by Carpenter et al. (1972) [11]. Many species of commercial fish such as cantang grouper, are contaminated by microplastics. Besides obstruction of the digestive tracts, microplastics can also inhibit the digestive processes and disrupt nutrition absorption [9, $12]$.

There are more concerns about the amount and also effects of microplastic particles inside the commercial fish gills and gastrointestinal tract throughout the world's ocean. However, there is no research about the microplastic abundance inside fish gills and gastrointestinal tract from Pulau Panjang, Serang, Banten. This study aimed to provide information about the amount and shapes of microplastics found inside the gills and gastrointestinal tract of cantang grouper that is collected from Pulau Panjang, Serang, Banten.

\section{Materials and method}

\subsection{Study area and sampling location}

Fish samples were collected from the floating net cage by the fisherman in Kampung Peres, Panjang Island, Serang, Banten.

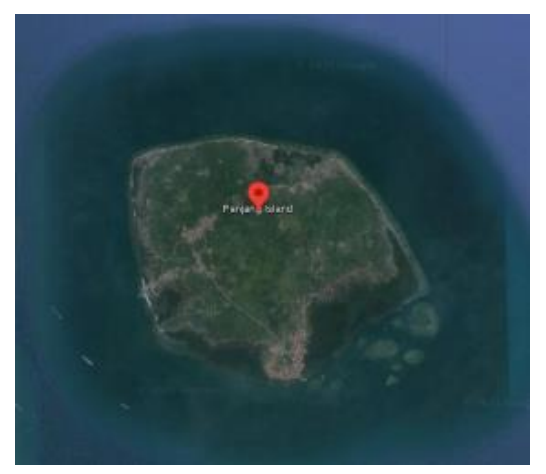

Fig. 1. Pulau Panjang, Serang, Banten, Indonesia.

\subsection{Sample collection}

A total of 15 cantang grouper E. fuscoguttatuslanceolatus samples were taken from the floating net cage near Kampung Peres, Pulau Panjang, Serang, Banten. Samples were then placed into an icebox and transported to the Marine Biology Laboratory, Department of Biology, Faculty of Mathematics and Natural Sciences, University of Indonesia. Samples were preserved in the refrigerator before dissection and extraction steps.

\subsection{Sample extraction and observation}

Gills and the gastrointestinal tract of the samples were isolated from their body using the dissection kit. Each isolated gills and gastrointestinal tract of the samples were placed into a sample bottle and immersed with $65 \%$ HNO3 solution for $24 \mathrm{~h}$ in a ratio of $1: 10$. The organ destruction step was implemented inside the fume hood/fume cupboard. The immersion results were diluted using saturated $\mathrm{NaCl}$ solution for $24 \mathrm{~h}$ in a ratio of 1:4 (HNO3 volume in $\mathrm{mL}: \mathrm{NaCl}$ in $\mathrm{mL}$ ) [35]. $\mathrm{NaCl}$ solution addition was done to increase the solution density. So that, it can separate the microplastic particles from the deposits [36].

The diluted solution was pipetted and transferred to a $20 \mathrm{~mL}$ Erlenmeyer flask for homogenization using a magnetic stirrer. Homogenized samples were taken 1 $\mathrm{mL}$ and dropped into the Sedgewick Rafter counting chamber to be observed under the light microscope [35]. Microplastic particles were counted using a hand counter and documented using a camera. The total average number of microplastic particles found in $1 \mathrm{~mL}$ of the observed samples was multiplied by $20 \mathrm{~mL}$ of the homogenized sample, it was done to obtain the microplastics value of the particles/L [35].

\subsection{Data processing and analysis}

The average value was obtained from three repetitions of each sample. Quantitative data obtained in the form of microplastic abundance were analyzed using Microsoft Excel and discussed.

\section{Results and discussion}

\subsection{Results}

Overall results from the observation that has been done on this research showed that microplastics abundance in Epinephelus fuscoguttatus-lanceolatus that was collected from the floating net cage in Pulau Panjang, Serang, Banten was 3459.56 \pm 1208.51 particles/individuals (gills) and 5595.11 \pm 2078.71 particles/individuals (gastrointestinal tracts). Microplastic abundance inside the gastrointestinal tract is higher, compared to microplastic abundance inside the gills. It can happen because E. fuscoguttatuslanceolatus is a carnivorous fish that feed on small planktivorous fishes. Microplastic that is contaminated by its prey's body can be ingested indirectly by $\mathrm{E}$. fuscoguttatus-lanceolatus, and it can be preserved for a long time inside their gastrointestinal tract [30].

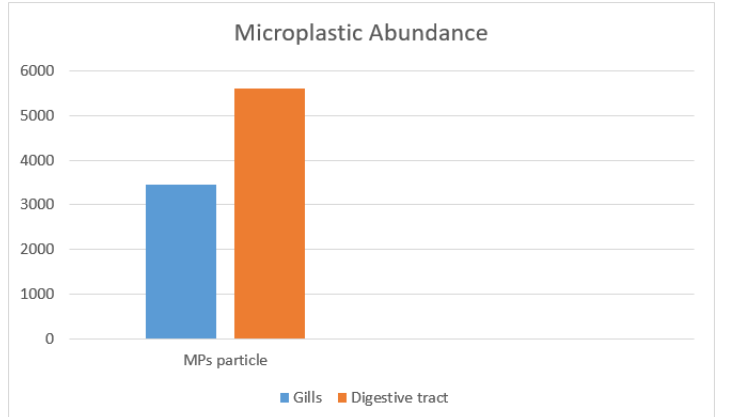

Fig.2.Microplastic abundance in E. fuscoguttatus lanceolatus. 
Four shape types of microplastic particles found in the gills and digestive tracts of $\mathrm{E}$. fuscoguttatus lanceolatus that found. There are fragment, fiber, film, and granule. Fragments are the most common type found in both gills and digestive tracts of E. fuscoguttatus lanceolatus.

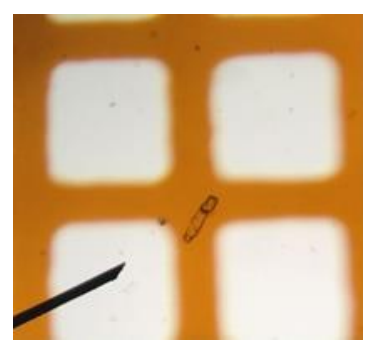

Fig.3.Fragment type found in E. fuscoguttatus lanceolatus.

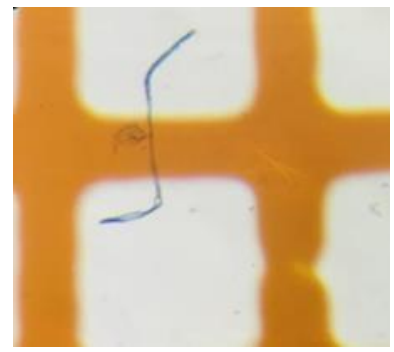

Fig.4.Fiber type (blue) found in E. fuscoguttatus lanceolatus.

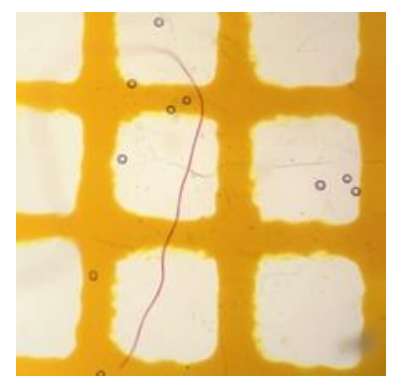

Fig.5.Fiber type (red) found in E. fuscoguttatus lanceolatus.

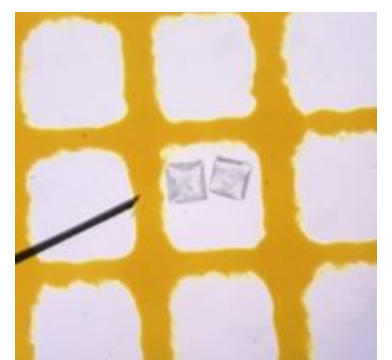

Fig. 6. Film type found in E. fuscoguttatus lanceolatus.

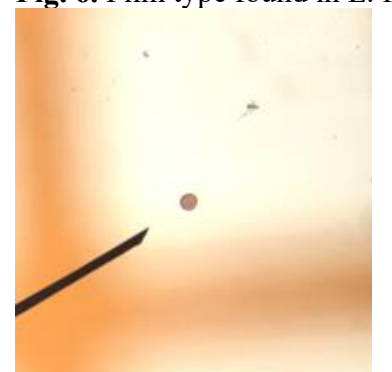

Fig.7.Granule type found in E. fuscoguttatus lanceolatus.

Fragment type of microplastics found were 1626.60 particles/individuals (gills) and 2383.66 particles/individuals (digestive tracts). Fiber type of microplastics found were 770.66 particles/individuals (gills) and 1769.34 particles/individuals (digestive tracts). Film type of microplastics found were 158.67 Particles/individuals (gills) and 14.33 particles/individuals (digestive tracts). Granule type of microplastics found were 39.77 parti- cle/individuals (gills) and 28.67 particles/individuals (digestive tract).

\subsection{Discussion}

Microplastic types found in the gills and gastrointestinal tract of E. fuscoguttatus-lanceolatus were fragment, fiber, film, and granule. The overall result shows that the gastrointestinal tract was a higher microplastic amount than the gills. A study of microplastic density in the gastrointestinal tract of commercial fish from Campeche Bay, Mexico, found that the abundance of microplastics in the gastrointestinal tract of fish can be mainly associated with the depth and the fish habitat where they feed [31].

Microplastic consumption by the fish and microplastic particles presence in seawater did not affect fish feeding behavior. The amount of microplastic found inside the gastrointestinal tract was influenced by the size of the microplastic itself. The smaller microplastic size, the more it is consumed by the fish. Certain sizes of microplastic can be recognized and avoided by the fish [34]. However, a huge amount of microplastic particles that are accumulated inside the fish body can clog the digestive tract, disrupt the digestive processes, or obstruct the absorption processes [13]. Microplastic particles inside the digestive tract can also affect fish appetite or carry chemical contaminants [14].

The fragment is the most common type of microplastic found in E. fuscoguttatus lanceolatus from Panjang Island, Serang, Banten. The fragment type of microplastics came from the degradation of plastic waste that occurs by the processes of photolysis or biodegradation [5]. The second common form of microplastic found in E. fuscoguttatus lanceolatus is fiber. Three kinds of fiber colors are found inside the gastrointestinal tract of E. fuscoguttatus lanceolatus, there are red, blue, and transparent. The fiber type of microplastics comes from the textile industries waste or various synthetic materials from fishing rods and nets [4].

The third form found in E. fuscoguttatus lanceolatus is film. A film has an irregular shape, thin, and more flexible than a fragment (Kovac et al. 2016). A film is a type of secondary plastic polymer that came from the fragmentation of plastic bags (Karapanagioti 2008). Granule has the smallest amount of microplastic found in E. fuscoguttatus lanceolatus. Granule is a type of microplastic that came from the raw material for making a product, such as beauty products [15].

Based on the sources, they can be divided into two, primary and secondary. Primary came from the textile material [20], abrasion of plastic objects during the production processes, and from the drilling fluids for oil and gas exploration [21]. Secondary came from the processes or plastic waste disposal to the ocean [21]. Plastic waste can enter the ocean through the waterways, 
illegal waste disposal, or be transferred by wind [22;20;21].

The marine biota, such as fish, can ingest microplastic accidentally. Microplastics can be ingested directly or indirectly. Plastic particles ingested directly when fish cannot distinguish whether it's their prey, or it's plastic. While indirectly is when the fish ingested plastic that is already contaminated inside of their prey's body or it adheres on their prey's body [29]. E. fuscoguttatus lanceolatus used in this study is a carnivore that feeds on tiny organisms such as small fish and shrimp. So that, they might be ingested microplastics indirectly from their prey. And its microplastics ingested by E. fuscoguttatus lanceolatus from their prey are preserved inside their gastrointestinal tract. Fish ingestion of microplastics can also be influenced by the level of plastic waste contamination caused by local waste [28].

Microplastic inside the fish body can be excreted from the fish by their feces, or it can also be preserved inside their gastrointestinal tract. Accumulation of microplastic inside the fish gastrointestinal tract can cause bioaccumulation and subsequent biomagnification to the fish during their lifespan [30]. There are several negative impacts of microplastic ingestion to the fish body, such as it can lower the fish growth rate and block enzyme production. According to Zhang et al. (2019) [12], microplastic particles in the fish body can inhibit foraging ability, inhibit digestive processes, disrupt nutrition absorption and reproduction health, and also lower the growth and development rate. Microplastic in the ocean can absorb the toxic that is harmful to many organisms. The toxic from the microplastic is generated from chemical compounds that are spread in the sea surface or the surrounding environment such as river, land, etc. Microplastic contamination in several biotas can also be transferred indirectly by the food chain [16].

\section{Conclusion}

There are four kinds of microplastic forms found inside the gills and gastrointestinal tract of Epinephelus fuscoguttatus-lanceolatus from Pulau Panjang, Serang, Banten. The fragment is the common form found in E. fuscoguttatus lanceolatus gills and digestive tracts, followed by fiber, film, and granule. The digestive tract has more microplastic abundance compared to the gills. An average microplastic abundance inside the gills is $3459.56 \pm 1208.51$ particles/individuals, and 5595.11 \pm 2078.71 particles/individuals inside the digestive tracts.

\section{References}

1. S.M.E. Cannon, J. L. Lavers, \& B. Figueredo (2016).

2. A. L. Andrady, The plastic in microplastic: a review. Marine pollution bulletin 119 (1) (2017) 12-22.

3. M. R. Cordova, A. I. S. Purwiyanto, \& Y. Suteja (2019).
4. J. Ding, J. Li, C. Sun, F. Jiang, P. Ju, L. Qu, Y. Zheng, \& C. He. Detection of microplastics in local marine organisms using a multi-technology system. Anal. Methods. 11 (2019) 78-87.

5. J. Reisser, J. Shaw, C. Wilcox, B. D. Hardesty, M. Proietti, M. Thums, \& C. Pattiaratchi. Marine plastic pollution in waters around Australia: Characteristics, concentrations, and pathway. PLoS ONE. (2013).

6. G.D. Jackson, N.G. Buxton, \& M. J. George, Diet of the southern opah Lampris immaculatus on the Patagonian Shelf; the significance of the squid Moroteuthis ingens and anthropogenic plastic. Mar. Ecol. Prog. Ser. 206 (2000) 261-271.

7. W. Kiswara, Dampak perluasan kawasan industry terhadap penurunan luas padang lamun di Teluk Banten. Balitbang Biologi, Puslitbang OseanologiLIPI (1994).

8. D. Ernaningsih, D. Simbolon, E. S. Wiyono \& A. Purbayanto. Zonasi pemanfaatan kawasan perikanan tangkap di Teluk Banten. Marine fisheries 2 (2011) 177-187.

9. C. I. S. Yudhantari, I.G.L. Hendrawan \& N.L.P.R. Puspita, Kandungan mikroplastik pada saluran pencernaan ikan lemuru protolan (Sardinella lemuru) hasil tangkapam di Selat Bali. JMRT 2 (2019) 47-51.

10. A. N. A.T. Rochmad, Mukti, Teknik pembesaran ikan kerapu hibrida cantang (Epinephelus fuscoguttatus x Epinephelus lanceolatus) pada keramba jaring apung. Jurnal biosains pascasarjana 22 (2020) 29-36.

11. E. J. Carpenter, J. S. Anderson, G.R. Harvey, H.P. Miklas \& B.B. Peck, Polystrene spherules in coastal waters. Science 178 (1972) 749-750.

12. F. Zhang, Y.B. Man, W.Y. Mo, K.Y. Man \& M. H. Wong, Direct and indirect effects of microplastics on bivalves, with a focus on edible species: A mini-review. Critical reviews in environmental science and technology (2019) 135

13. S.L. Wright, R.C. Thompson, \& T.S. Galloway, The physical impacts of microplastics on marine organisms: a review. Environmental pollution 178 (2013) 483-492.

14. Hirai, Organic micropollutants in marine plastics debris from the open ocean and remote and urban beaches. Marine pollution bulletin 62(8) (2011) 1682-1683.

15. H. W. Ji \& S. S. Yoo, Intl Journal Apllied Science. v 13 (2018) 677-88.

16. C. G. Avio, S. Gorbi \& regoli F, Plastics and microplastics in the ocean: from emerging pollutions to emrged threat (Marine environment research) v 128 (2016) 2-11.

17. United Nations Environment Programme, UNEP Frontiers 2016 reports: Emerging Issues of environmental concern. UNEP, (2016). 
18. M. A. Browne, P. Crump, S.J. Niven, E. Teuten, A. Tonkin, T. Galloway, \& R. Thompson, Accumulation of microplastics on shorelines worldwide: sources and sinks. Environ, Sci. Technol. 45(21) (2011) 9175-9179.

19. P. G. Ryan, C.J. Moore, J.A. van Franeker, \& C.L. Moloney, Monitoring the abundance of plastic debris in the marine environment. Philosophical transaction of the royal society B: Biological sciences 364(1526) (2009) 1999-2012.

20. K. Duis \& A. Coors, Microplastics in the aquatic and terrestrial environment: Sources (with a specific focus on personal care products), fate and effects. Environmental sciences Europe 28 (2016) $1-25$.

21. J. Boucher \& D. Friot. Primary microplastics in the Oceans: a global evaluation of sources. IUCN (2017)

22. J. R. Jambeck, R. Geyer, C. Wilcox, T.R. Siegler, M. Perryman, A. Andrady, R. Narayan \& K.L. Law. Plastic waste inputs from land into the ocean. Science 347 (2016) 768-770.

23. R. Geyer, J. R. Jambeck \& K. L. Law. Production, usem and fate of all plastics ever made. Science advances. 3 (2017).

24. Kementerian Keuangan Republik Indonesia. media keuangan (transparansi informasi kebijakan fiskal). Bumi dalam kantong plastik. 14 (2019) 1907-6320.

25. I. Prayogo \& W. Isfanji. Teknik pemeliharaan larva kerapu cantang (Epinephelus fuscoguttatus lanceolatus). Jurnal ilmu perikanan. 5 (2014) 1319.

26. S. Ismi. Beberapa macam cacat tubuh yang terjadi pada benih ikan kerapu cantang hasil hatchery. Journal of fisheries and marine research. 4 (2020) 94-101.

27. S. Ismi, Y. N. Asih, \& D. Kusumawati. Peningkatan produksi dan kualitas benih kerapu dengan program hibridisasi. Jurnal oseanologi Indonesia. 1 (2014) 1-5.

28. T. Romeo, B. Pietro, C. Peda, P. Consoli, F. Andaloro, \& M. C. Fossi. First evidence of presence of plastic debris in stomach of large pelagic fish in the Mediterranean Sea. Mar.Pollut.Bull. 95 (2015) 358-361.

29. M. Cole, P. Lindeque, E. Fileman, C. Halsband, R. Goodhead, J. Moger, \& T. S. Galloway. Microplastic ingestion by zooplankton. Environ. Sci. Technol. 47 (2013) 6646-6655.

30. S. Roch, C. Friederich, \& A. Brinker. Uptake routes of microplastics in fishes: practical and theoretical approaches to test existing theories. Sci. Rep. 10 (2020).

31. M. B. R. Merle, F. M. F. Edgar, E. S. Griselda, \& R. O. Jaime. Plastic density as a key factor in the presence of microplastic in the gastrointestinal tract of commercial fishes from Campeche Bay,
Mexico. Environmental Pollution. 267 (2020) 110.

32. A. Dabrowska, I. Lopata, \& M. Osial. The ghost nets phenomena from the chemical perspective. Pure. Appl. Chem. 93 (2021) 479-496.

33. S. Anbumani \& P. Kakkar. Ecotoxicological effects of microplastics on biota: a review. Environ. Sci. Pollut. Res. 25 (2018) 14373-14396.

34. K. Critchell \& M. O. Hoogenboom. Effects of microplastic exposure on the body condition and behaviour of planktivorous reef fish (Acanthochromis polyacanthus). PLoS ONE. 13 (2018).

35. H. R. Ukhrowi, W. Wardhana, M. P. Patria. Microplastic abundance in blood cockle (Linnaeus 1758) at Lada Bay, Pandeglang, Banten” Journal of Physiscs: Conference Series. (2021)

36. J. Masura, J. E. Baker, G. D. Foster, C. Arthur, \& C. Herring. Laboratory methods for the analysis of microplastics in the marine environment: recommendations for quantifying synthetic particles in waters and sediments. (2015) 1-39. 